\title{
Emergency nurses' attitudes towards the concept of witnessed resuscitation
}

\author{
Ana Laura García-Martínez' \\ Cristóbal Meseguer-Liza²
}

\begin{abstract}
Objective: to review the most relevant evidence on the nurses' attitudes towards witnessed resuscitation, in the inpatient and out-of-hospital spheres. Method: integrative literature review, covering the period from 2008 till 2015, using the databases PubMed, Lilacs and SciELO; in Spanish, English and Portuguese. The pediatric context was excluded from the study. Results: the synthesis of the data resulted in the inclusion of 10 articles, categorized as: positive attitudes and negative attitudes. Conclusions: discrepancies exist among the nurses from different contexts and geographical regions towards the concept; protocols need to be established for this situation, in view of the advantages evidenced in the literature, for the nursing professionals as well as the relatives. Witnessed resuscitation can represent an opportunity to understand and cope with the rational and irrational in the situation in a shared manner, as well as mitigate or dignify the mourning.
\end{abstract}

Descriptors: Cardiopulmonary Resuscitation; Heart Arrest; Attitude of Health Personnel; Emergency Nursing; Family Relations.

${ }^{1} \mathrm{PhD}$, Researcher, Universidad de Murcia, Murcia, Spain.

2 PhD, Assistant Professor, Universidad de Murcia, Murcia, Spain.

\section{How to cite this article}

García-Martínez AL, Meseguer-Liza C. Emergency nurses' attitudes towards the concept of witnessed resuscitation. Rev. Latino-Am. Enfermagem. 2018;26:e3055. [Access DOI: http://dx.doi.org/10.1590/1518-8345.1382.3055. month day year ; Available in: 


\section{Introduction}

Research on the family's presence during resuscitation maneuvers ${ }^{(1)}$ - in the pre-hospital context, defined as the presence and participation of one or more family members in the patient care area, in a place that enables them to have visual and/or physical contact with the patient - started in the 1980's in the hospital context, particularly at the Foote Hospital in Jackson, Michigan (USA). At that time, the procedure and the traditional medical attitude to the patient's relatives were questioned, after relatives had requested to be present on two occasions.

As a general standard, at countless inpatient and out-of-hospital services, the professionals try to distance the relatives from the victims of a cardiorespiratory arrest, with a view to avoiding that they hinder the professionals during the application of cardiopulmonary resuscitation techniques. Excluding the relatives is justified under the premise that the invasive procedures and the aggression during the cardiopulmonary resuscitation can provoke stress in the family members and that their presence could compromise the performance of the medical team ${ }^{(2)}$.

The literature review, however, presents contradictory results concerning the meaning of the concept of family presence during the resuscitation maneuvers and the nursing professionals' attitudes, adding positive and negative opinions and provoking a continuous debate.

The objective in this study is to review the most relevant evidence on the nurses' attitudes towards the presence of relatives during cardiopulmonary resuscitation maneuvers inpatient and out-of-hospital services. The idea to have a family member present during the cardiopulmonary resuscitation is supported(3) and underwritten by different international organizations, such as the Emergency Nurses Association (ENA), the American Heart Association (AHA) and the European Resuscitation Council(4-5).

The lack of protocols on the witnessed resuscitation concept arouses controversies about ethical-care issues deriving from health practice.

\section{Method}

An integrative literature review was undertaken, covering the period from 2008 to 2015. As for the databases related to the health sciences, PubmedMedline, Lilacs and Scielo were used. The bibliographic search in the databases was based on the following descriptors and/or key words: Cardiopulmonary Resuscitation, Heart Arrest, Attitude of Health Personnel,
Emergency Nursing, Family presence/Witness; in Spanish, English and Portuguese; the following inclusion criteria were used: presence of relatives during the cardiopulmonary resuscitation maneuvers; application of invasive techniques that might be necessary in the procedure and inpatient and out-of-hospital emergency services for adults. Both the qualitative and quantitative method were included in the review.

Therefore, articles related to the pediatric context and articles referring to critical and intensive care services were excluded.

To facilitate the research process, the following guiding question was formulated: Which are the attitudes of emergency nurses to the concept of witnessed resuscitation?

In view of the lack of methodological uniformity for the integrative reviews, in order to analyze the documents, the methodological structure of the systematic review ${ }^{(6)}$ was used for support, which consisted in the reduction, visualization, comparison, conclusion and verification of the data. In the first phase of data reduction, the categories are identified, which facilitates the analysis; in the visualization phase, the information from the studies was registered; in the comparison of the data, the similarities and differences among the findings were verified; and in the conclusion, the main elements were summarized.

Among the 20 final articles that could be included in the review, ten were analyzed in accordance with the criteria of relevance and pertinence, including this total in Figure 1. The extent of the document obliged us to give preference to articles that represented the nurses' attitudes to the concept of witnessed resuscitation with higher quality.

Besides the impact factor of the journal from which the article was taken, the following criteria were adopted: surprising results; theoretical and practical importance; new and interesting ideas; new framework; internal validity: use of appropriate design and method; external validity; the presented results and/or theory are generalizable; sufficient description of the method and procedure for other researchers to replicate them; theoretical or practical results with a high degree of implementation; theoretical or practical results useful to society; and clear specification of the type of study. In addition, the intention was to create a synthetic document, for which those articles were selected that truly offer a determining contribution.

Concerning the limitations of the study, it is highlighting that, given the novel nature of the theme, after applying the filters established, the number of records was limited. This justifies the need to expand the research in this field. 


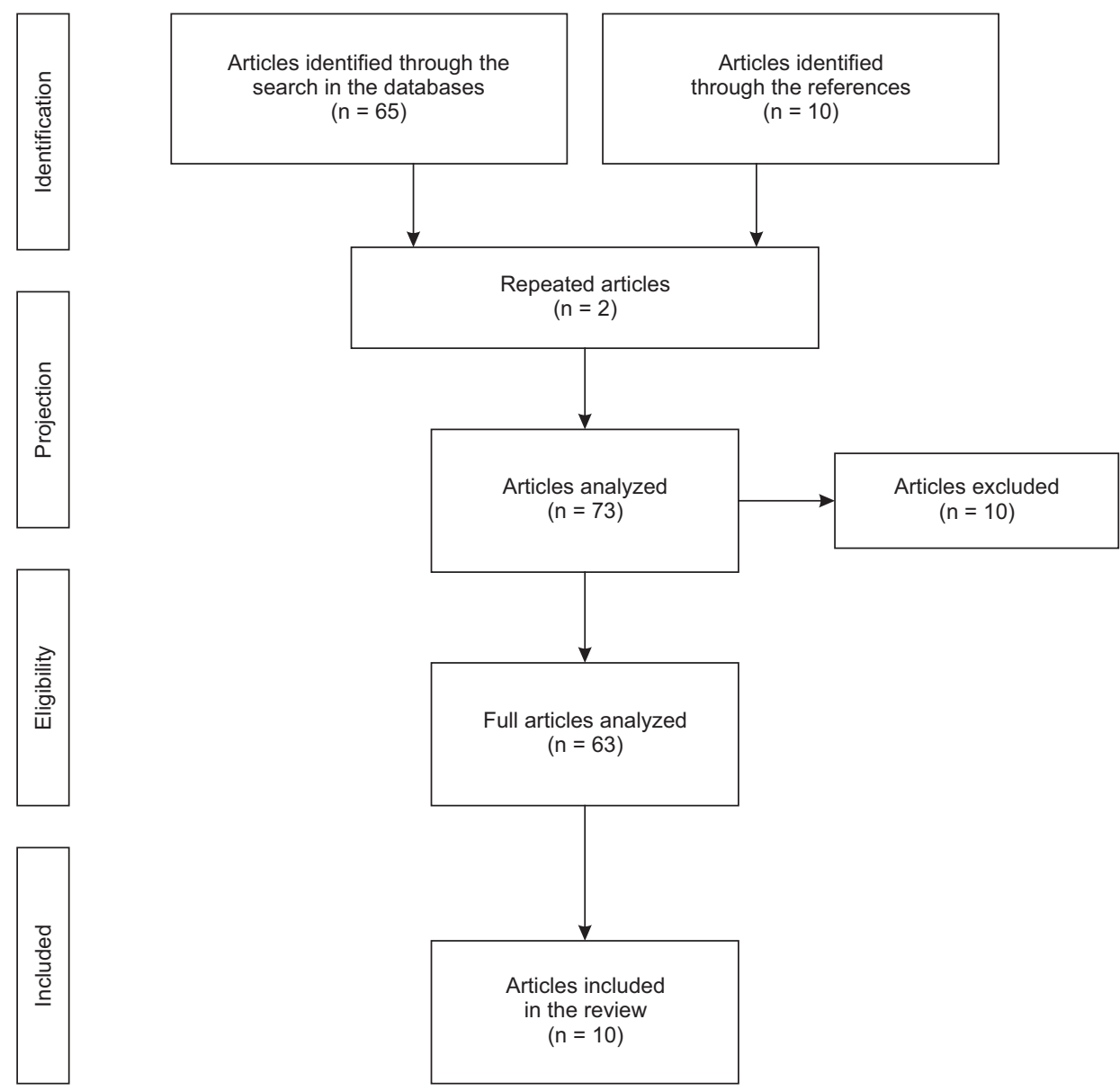

Figure 1 - Selection process of the studies in the databases

\section{Results}

The ten articles included in the review produced two subcategories related to the attitudes and emotions of the nursing professionals about the concept witnessed resuscitation. It should be highlighted that most of the articles analyzed come from English-language literature,
$92 \%$ being located in the database Web of Science, $7 \%$ in Lilacs and $1 \%$ in Scielo.

Figure 2 analyzes the most relevant articles in the integrative review and their most significant results, from which two categories are derived on the emergency nurses' attitudes towards the concept of witnessed resuscitation.

\begin{tabular}{|c|c|c|c|}
\hline $\begin{array}{l}\text { Studyl } \\
\text { year }\end{array}$ & $\begin{array}{c}\text { Sample/ } \\
\text { study design }\end{array}$ & $\begin{array}{l}\text { Positive attitudes towards } \\
\text { witnessed resuscitation }\end{array}$ & $\begin{array}{l}\text { Negative attitudes towards } \\
\text { witnessed resuscitation }\end{array}$ \\
\hline $\begin{array}{l}\text { García de } \\
\text { Alba García, } \\
\text { García } \\
\text { Regalado, } \\
\text { Salcedo } \\
\text { Rocha }^{(7)} \\
2010\end{array}$ & $\begin{array}{l}\text { Bibliographic review covering the } \\
\text { last } 15 \text { years of English-language } \\
\text { literature. } \\
\text { Descriptive studies, } 2 \text { experimental, } \\
24 \text { quantitative and } 4 \text { qualitative. } \\
5 \text { ethical studies. }\end{array}$ & $\begin{array}{l}\text { Being present during the resuscitation } \\
\text { provokes tranquility and satisfaction in the } \\
\text { family members. } \\
\text { The education increases the number of } \\
\text { nurses who consider that witnessed CPR is } \\
\text { participatory. } \\
\text { The patient's survival is important, but so is } \\
\text { attending to the family. }\end{array}$ & $\begin{array}{l}\text { The technique has disruptive effects on the } \\
\text { work of the health team. } \\
\text { Need to protect the patients' privacy. } \\
\text { The team is afraid of focusing more on the } \\
\text { family's needs than on the patient's needs and } \\
\text { on the relatives' possible reactions. }\end{array}$ \\
\hline $\begin{array}{l}\text { Marcela } \\
\text { Achury }^{(8)} \\
2010\end{array}$ & Bibliographic literature review. & $\begin{array}{l}\text { Opportunity to provide emotional and spiritual } \\
\text { support and guidance to the patients' relatives, } \\
\text { which enhances the understanding of the } \\
\text { situation, favors decision making on the } \\
\text { resuscitation based on the quality of life and } \\
\text { facilitates the mourning process. } \\
\text { Feeling of empathy by the nurses. }\end{array}$ & $\begin{array}{l}\text { Fear related to the professionals' lack of trust } \\
\text { in stress situations. } \\
\text { Fear of the possible legal consequences that } \\
\text { might emerge. }\end{array}$ \\
\hline
\end{tabular}




\begin{tabular}{|c|c|c|c|}
\hline $\begin{array}{l}\text { Studyl } \\
\text { year }\end{array}$ & $\begin{array}{c}\text { Sample/ } \\
\text { study design }\end{array}$ & $\begin{array}{l}\text { Positive attitudes towards } \\
\text { witnessed resuscitation }\end{array}$ & $\begin{array}{l}\text { Negative attitudes towards } \\
\text { witnessed resuscitation }\end{array}$ \\
\hline $\begin{array}{l}\text { García } \\
\text { Regalado(9) }_{2011}\end{array}$ & $\begin{array}{l}\text { Descriptive and observational cross- } \\
\text { sectional study with qualitative and } \\
\text { quantitative focus. } \\
\text { The sample was selected in the } \\
\text { adult Emergency Area of hospitals in } \\
\text { Western Mexico. }\end{array}$ & $\begin{array}{l}\text { Acceptance, Effort, Knowledge, Tranquility, } \\
\text { Quality, Compliance, Mourning, Empathy, } \\
\text { Rights, Promotion. } \\
\text { Experiences: Tranquility, Traumatic, } \\
\text { Acceptance, Satisfactory, Effort, Difficult }\end{array}$ & $\begin{array}{l}\text { Trauma, Negligence, Deficiency, Ignorance, } \\
\text { Numbness, Stress, Failure, Misinterpretations. } \\
\text { Experiences: Misunderstanding, Unpleasant, } \\
\text { Depressing, Deficiency, Anxiety, Despair, } \\
\text { Stressed, Nervousness. }\end{array}$ \\
\hline $\begin{array}{l}\text { Michal } \\
\text { Itzhaki, } \\
\text { Yoram Bar- } \\
\text { Tal, Sivia } \\
\text { Barnoy } \\
2012\end{array}$ & $\begin{array}{l}\text { Factorial design with two variables: } \\
\text { presence/absence of relatives during } \\
\text { resuscitation versus resuscitated } \\
\text { or dead patient. The dependent } \\
\text { variables were the staff's perceived } \\
\text { answers and family presence during } \\
\text { the resuscitation. }\end{array}$ & $\begin{array}{l}\text { The witnessed resuscitation offers benefits for } \\
\text { relatives and professionals. }\end{array}$ & $\begin{array}{l}\text { Feelings of emotional pressure in the } \\
\text { professionals involved. } \\
\text { Contradictory feelings. }\end{array}$ \\
\hline $\begin{array}{l}\text { Diana } \\
\text { Marcela } \\
\text { Achury } \\
\text { Saldaña, et } \\
\text { al (11) } \\
2012\end{array}$ & Bibliographic and descriptive review. & $\begin{array}{l}\text { The perception varies according to the } \\
\text { experiences lived in the professional context. } \\
\text { Nursing was the group most in favor. } \\
\text { Supports decision making on the patient's } \\
\text { resuscitation depending on his condition. }\end{array}$ & $\begin{array}{l}\text { Traumas for the professionals and relatives. } \\
\text { Chaos. } \\
\text { Confusion. } \\
\text { Greater stress for tasks involving the patients. }\end{array}$ \\
\hline $\begin{array}{l}\text { Jabre } P^{(12)} \\
2013\end{array}$ & $\begin{array}{l}\text { Prospective, randomized and } \\
\text { controlled cluster study, in which } \\
\text { the proportion of posttraumatic } \\
\text { stress is analyzed } 90 \text { days after } \\
\text { the resuscitation in the presence of } \\
\text { relatives. }\end{array}$ & $\begin{array}{l}\text { Significant reduction in posttraumatic stress in } \\
\text { the intervention group. } \\
\text { The family presence did not cause stress and } \\
\text { no further medical-legal conflicts were found. }\end{array}$ & $\begin{array}{l}\text { No negative outcomes were found concerning } \\
\text { the nurses' attitudes. }\end{array}$ \\
\hline $\begin{array}{l}\text { Tudor K et } \\
\text { al }^{(13)} \\
2014\end{array}$ & $\begin{array}{l}\text { Descriptive and cross-sectional } \\
\text { study, using a validated opinion poll } \\
\text { about resuscitation, applied to } 154 \\
\text { nurses. }\end{array}$ & $\begin{array}{l}\text { Nursing perceives the relatives' tranquility } \\
\text { they feel when they witness that everything } \\
\text { possible is being done for their loved ones as } \\
\text { the main benefit of witnessed resuscitation. }\end{array}$ & $\begin{array}{l}\text { Nursing perceives the possibility of family } \\
\text { members' interference in the maneuvers } \\
\text { as one of the most important barriers for } \\
\text { witnessed resuscitation. } \\
\text { Responding to the relatives' needs during the } \\
\text { cardiac arrest is not feasible for nursing due to } \\
\text { the lack of staff. }\end{array}$ \\
\hline $\begin{array}{l}\text { Flanders } \\
\text { SA, Strasen } \\
\text { JH.(14) } \\
2014\end{array}$ & Literature review & $\begin{array}{l}\text { Improves communication between the staff } \\
\text { and the family. } \\
\text { The staff could explain the resuscitation to the } \\
\text { family. } \\
\text { Makes it easier for the family to accept the } \\
\text { death. } \\
\text { Grants the family a feeling of control. } \\
\text { Facilitates the mourning process for the family. } \\
\text { The family members appreciate that } \\
\text { everything possible was done for their loved } \\
\text { one. } \\
\text { The family can decide in making decisions } \\
\text { concerning non-resuscitation orders. }\end{array}$ & $\begin{array}{l}\text { Conflicts among the team members due to } \\
\text { different attitudes and opinions. } \\
\text { Medical-legal aspects. } \\
\text { Distraction interferes in the team. } \\
\text { Risk for the security of the resuscitation team. } \\
\text { Need to comply with legal and forensic } \\
\text { standards. } \\
\text { Need for additional staff and increased costs. } \\
\text { Stress for the staff related to being observed. }\end{array}$ \\
\hline $\begin{array}{l}\text { Porter JE(15) } \\
2015\end{array}$ & $\begin{array}{l}\text { Development of validated survey of } \\
\text { emergency professionals' attitudes } \\
\text { towards witnessed resuscitation. }\end{array}$ & $\begin{array}{l}\text { The professionals agreed to allow the relatives } \\
\text { to say farewell to their loved ones. } \\
\text { The alternative staff figure is necessary. } \\
\text { Increased personal and professional } \\
\text { satisfaction. }\end{array}$ & $\begin{array}{l}\text { The emergency staff maintains its reservations } \\
\text { towards the witnessed resuscitation. }\end{array}$ \\
\hline $\begin{array}{l}\text { Goldberger } \\
\text { ZD }^{(16)} \\
2015\end{array}$ & Observational cohort study. & $\begin{array}{l}\text { The existence of witnessed resuscitation } \\
\text { policies at the emergency services of the } \\
\text { hospitals studied did not influence the } \\
\text { resuscitation efforts. }\end{array}$ & $\begin{array}{l}\text { Although the CPR guides manifest the } \\
\text { benefits of witnessed resuscitation, many } \\
\text { professionals do not accept them. }\end{array}$ \\
\hline
\end{tabular}

Figure 2 - Most relevant results concerning witnessed resuscitation

\section{Discussion}

The main result this integrative review contributes relates to the controversies among the resuscitation team members regarding the concept of witnessed resuscitation; that is so although the most recent CPR guides, such as the guides of the American Heart Association and the European Resuscitation Council(17), identify the benefits of applying family presence policies during the resuscitation maneuvers, respecting the cultural and social values of the family members and even of the professionals involved.

The concept generates an ongoing debate among the nurses, with great variation in the perceived risks or benefits of the family members' presence ${ }^{(18)}$. Furthermore, in this study, the findings suggest that 
the perceptions of the nurses who granted the relatives the opportunity to witness the resuscitation differ from the perceptions of those who did not; the former perceive greater benefits and the emergency nurses are the most willing to invite the relatives to witness the resuscitation.

Qualitative research on witnessed resuscitation could reveal more concrete aspects than quantitative studies and reveal specific benefits of the family's presence during the resuscitation event. Recent qualitative studies(19) highlight the need for the nursing professionals to support the family members when deciding on whether to witness the resuscitation or not.

The literature review shows us results on the existing relation between the nature of the background experience in witnessed resuscitation situations and their attitudes(20). The nurses who informed on positive experiences had significantly more favorable attitudes when considering the benefits of witnessed resuscitation: less fear of negative consequences and less personal and organizational barriers.

Less articles were found in Spanish. Among these, a qualitative study ${ }^{(21)}$ should be highlighted though, in which the in-depth interviews revealed three main themes concerning the attitudes of nurses active in witnessed resuscitation: unsafe practice, empathetic experience and necessary practice. The positive attitudes were: wellbeing, pride, consolation, conciliation, responsibility, experience, tranquility and acknowledgement. Negative attitudes were: sadness, impotence, stress, nervousness, insecurity, logistics, pressure, anxiety, anguish, lack of control and pressure.

In short, the nurses' attitudes in executing witnessed resuscitation maneuvers before relatives are dynamically concentrated in these main themes during the maneuvers through different emotions, conducts and behaviors, distributed between signifying a negative experience that affects the professional wellbeing or a positive experience leading to the resilience of nursing. A team member needs to support the relatives during the resuscitation maneuvers.

In the end, the literature review shows us important benefits of witnessed resuscitation. In addition, most of the nurses consider that, when accomplishing the resuscitation maneuvers in the presence of relatives, their stress, lack of control and emotional tension neither provoke interference nor hamper the nurse's work; thus, the family's presence is valued, considering it as beneficial, stress reducing and facilitating the mourning process, which is a right of the patient and the family.

\section{Conclusion}

The literature review shows multiple studies on the emergency nurses' attitudes, in which we can distinguish two categories that contain the different attitudes the witnessed resuscitation event produces; these can be summarized as follows:

- Positive attitudes: tranquility, empathy, safety, pride and facilitating the mourning process. The witnessed resuscitation can be an opportunity to understand and confront the rational and irrational in the situation in a shared manner and to mitigate or dignify the mourning. - Negative attitudes: stress, fear, impotence and mainly the feeling that the family members can make the accomplishment of the resuscitation maneuvers more difficult.

The evidence shows the multiple benefits of witnessed resuscitation, as being present during the resuscitation provokes tranquility and satisfaction in the relatives, as well as the need to actively prepare the nurses to enhance their confidence in view of the management of the concept, which justifies the need to establish protocols for this situation. The establishment of agreed protocols would be recommended, which identify when, how and to whom the witnessed resuscitation should be offered.

In the light of the review, it was verified that witnessed resuscitation is a controversial and current team in intra and out-of-hospital emergency care, leaving many unanswered questions nowadays. In that sense, the health professionals are immersed in a great emotional debate in their daily work, when they need to perform violent, invasive techniques or maneuvers in the presence of family members, under the emotional burden this action provokes. Therefore, discrepancies emerge among the nurses from different contexts and geographical zones with regard to the concept of witnessed resuscitation.

It should be kept in mind that the extra-hospital environment is hostile, in which we can often feel unprotected, for example, when a patient is resuscitated at his own home, in the presence of the family, listening to what the team comments; this moment requires great physical and mental effort towards the victim of the cardiac arrest. Nevertheless, it should never be forgotten that the family will need our support; hence, a holistic and comprehensive focus needs to be established in view of the family's needs.

Concerning the implications of the findings for professional practice, the knowledge and study of the witnessed resuscitation concept and the attitudes observed in the nurses could consolidate its promotion and use, due to the different benefits of this technique 
the studies evidenced, although some controversies were evidenced; we found a higher value of the nursing professionals' attitudes. In fact, two branches of the implications were visible: an immediate implication that reflects the safety in practice and the defense of the patient's values (principle of autonomy), and another indirect implication, which is related to the consequences for the relatives in terms of an easier mourning process.

Finally, the need to investigate new and different approaches to witnessed resuscitation should be emphasized in the different areas in which nursing establishes its resuscitation work, from the perspective of the people who are experiencing this. Therefore, the use of the qualitative method should be boosted as a complement to the quantitative method, in order to understanding how the family's presence during the resuscitation maneuvers is perceived.

\section{References}

1. Eichhorn DJ, Meyers TA, Guzzetta CE, Clark AP, Klein JD, Talieaferro E, et al. Family presence during invasive procedures and resuscitation: hearing the voice of the patient. Am ] Nurs. [Internet] 2001 [Access Jan 11, 2015];101(5): 48- 55. Available from: www.jstor.org/ stable/3522401

2. Robinson S.M, Mackenzie-Ross S, Campbell G.L, Egleston C.V, Prevost A.T. Psychological effect of witnessed resuscitation on bereaved relatives. Lancet. [Internet] 1998 [Access February 12, 2016];352(9128):614-7. Available from: http://dx.doi. org/10.1016/S0140-6736(97)12179-1

3. Project Team of the Resuscitation Council (UK). Should Relatives Witness Resuscitation? [Internet]. Londres; Resuscitation Council (UK) 1996. Access March 14, 2016. Available from: http://hdl.handle.net/10068/432688 4. American Heart Association (AHA). Ethical Aspects of CPR and ECC. Circulation. [Internet]. 2000 [Access May 9, 2016];102:112-21. Available from: http://dx.doi. org/10.1016/S0300-9572(00)00270-7

5. Baskett PJF, Steen PA, Bossaert L. European Resuscitation Council Guidelines for Resuscitation 2005. Section 8 The ethics of resuscitation and end-of-life decisions. Resuscitation. [Internet]. 2005 [Access May 9, 2016];67(Suppl 1):S171-80. Avaiable from: http:// dx.doi.org/10.1016/j.resuscitation.2005.10.005

6. Souza MT, Silva MD, Carvalho R. Revisão integrativa: o que é e como fazer. Einstein. [Internet]. 2010 [Acesso 11 Maio 2016]; 8(1):102-6. Disponível em: http:// astresmetodologias.com/material/O_que_e_RIL.pdf 7. García de Alba García JE, García Regalado JF, Salcedo Rocha AL. Reanimación Cardiopulmonar Presenciada en el contexto hospitalario mexicano. Desacatos. [Internet]. 2010 [Acceso Enero 12, 2016];(34):149-64. Disponible en: http://www. scielo.org. mx/scielo.php?script=sci_arttext\&pid=S140592742010000300010\&lng=es\&tlng=es.

8. Marcela Achury D, Achury Beltrán LF. Presencia de la familia en la Reanimación cerebrocardiopulmonar. Enferm Cardiol. [Internet]. 2010 [Acceso 11 Febrero, 2016]; (50): 52-6. Disponible en: https:// www.enfermeriaencardiologia.com/wp-content/ uploads/50_08.pdf

9. García Regalado JF, García de Alba García JE, Salcedo Rocha AL. Opinión del personal médico y paramédico en las salas de urgencias en los hospitales del centro del país sobre reanimación presenciada. Una perspectiva mexicana de las recomendaciones ACLS. Arch Med Urgencia México. [Internet]. 2011 [Acceso 13 Marzo, 2016]; 3(2): 55-61. Disponible en: http://www. medigraphic.com/archivosdemedicinadeurgencia.

10. Itzhaki M, Yoram Bar-Tal, Barnoy S. Reactions of staff members and lay people to family presence during resuscitation: the effect of visible bleeding, resuscitation outcome and gender. J Adv Nurs. [Internet] 2012 [Access March 11, 2016]; 68(9): 1967-77. Available from: http://onlinelibrary.wiley.com/doi/10.1111/j.13652648.2011.05883.x/epdf

11. Achury D, Arango OJ, García G, Herrera N. Percepciones relacionadas con la presencia de la familia en escenarios avanzados como la reanimación cerebro cardiopulmonar. 2012; 14(1): 75-92. Disponible en: http://revistas. javeriana.edu.co/index.php/imagenydesarrollo/article/ viewFile/3179/2420

12. Jabre P, Belpomme V, Azoulay E, Jacob L, Bertrand L, Lapostolle F, Tazarourte K, Bouilleau G, Pinaud V, Broche $\mathrm{C}$, et al. Family Presence during Cardiopulmonary Resuscitation. N Engl J Med. [Internet]. 2013[Access Mar 14, 2015]; 368(11):1008-18. Available from: http://search.proquest.com/docview/1316941469?acco untid $=50037$

13. Tudor K, Berger J, Polivka BJ, Chlebowy R, Thomas B. Nurses' perceptions of family presence during resuscitation. Am J Crit Care. [Internet]. 2014 [Access Nov 23, 2015]; 23(6): e88-96. Available from: http:// ajcc.aacnjournals.org/content/23/6/e88.short

14. Flanders SA, Strasen JH. Review of evidence about family presence during Resuscitation. Crit Care Nurs Clin North Am. 2014 Dec; 26(4):533-50. doi: 10.1016/j. ccell.2014.08.010.

15. Porter JE, Cooper SJ, Taylor B. Family presence during resuscitation (FPDR): A survey of emergency personnel in Victoria, Australia. Australian Emerg Nurs J. [Internet]. 2015 [Access May 14, 2016];18(2): 98-105. Available from: http://doi:10.1016/j. aenj.2014.12.003 
16. Goldberger ZD, Nallamothu BK, Nichol G, Chan PS, Curtis JR, Cooke CR. Policies allowing family presence during resuscitation and patterns of care during in-hospital cardiac arrest. Circ Cardiovasc Qual Outcomes. [Internet]. 2015 [Access May 18, 2016];8(3):226-34. Available from: http://circoutcomes.ahajournals.org/lookup/suppl/ doi:10.1161/CIRCOUTCOMES.114.001272/-/DC1.

17. Monsieurs KG, Nolan JP, Bossaert LL, Greif R, Maconochie IK, Nikolaou NI et al. Resuscitation. [Internet]. 2015 [Access jan 19, 2016];95:1-80. Available from: http://10.1016/j.resuscitation.2015.07.038.

18. Twibell RS, Siela D, Riwitis C, Wheatley J, Riegle $T$, Bousman $D$ et al. Nurses perceptions of their selfconfidence and the benefits and risk of family presence during Resuscitation. Am Crit Care. [Internet]. 2008 [Access Jan 11, 2015];17(2):101-11. Available from: http://ajcc.aacnjournals.org/content/17/2/101.long

19. Twibell rs, Craig S, Siela D, Simmonds S, Thomas

C. Being there: Inpatients Perceptions of family presence during Resuscitation and invasive cardiac procedures. Am J Crit Care. [Internet] 2015 [Access Feb 21, 2016]; 24(6): e108-15. Available from: http:// www.ajcconline.org

20. Sak-Dankosky N, Andruszkiewicz P, Sherwood PR, Kvist T. Factors associated with experiences and attitudes of healthcare professionals towards family-witnessed Resuscitation: a cross-sectional study. J Adv Nurs. [Internet]. 2015 [Acceso 11 Feb 2016];71(11):2595608. Available from: http://onlinelibrary.wiley.com/ doi/10.1111/jan.12736/epdf.

21. Silva Dall'Orso M, Jara Concha P. Presencia familiar durante la reanimación cardiopulmonar: la mirada de enfermeros y familiares. Cienc Enferm. [Internet]. 2012 [Acceso 10 Enero 2015];18(3):83-99. Disponible en: http://dx.doi.org/10.4067/S0717-95532012000300009 Creative Commons (CC BY).

This license lets others distribute, remix, tweak, and build upon your work, even commercially, as long as they credit you for the original creation. This is the most accommodating of licenses offered. Recommended for maximum dissemination and use of licensed materials. 